\title{
Stability and Variability of the Herb and Volatile Oil Traits in Geranium (Pelargonium graveolens)
}

\author{
Mohamed A. F. A. El-Tahawey, Amani H. A. M. Gharib and A. A. El Sayed \\ Department of Vegetables, Medicinal and Aromatic Plant Breeding, Horti. Res. Inst., Agriculture Research Center,
} Giza, Egypt

Received: $19 / 11 / 2020$

\begin{abstract}
Geranium; (Pelargonium graveolens) is one of the important medicinal and aromatic plants in Egypt, its essential oil is rose like odor and commercially used in high-grade soaps, cosmetics and perfumes. This investigation was carried out to study the stability analysis and variability for eight herb and oil traits (plant height, fresh weight/plant, fresh weight of herb/plant, fresh weight of root/plant, volatile oil percentage, volatile oil yield/plant, herb fresh weight/fedan and volatile oil yield/fedan) in geranium (Pelargonium graveolens) by growing 3 clones which were collected from different regions of Egypt, Al-Sharkia (G1), Ismailia (G2) and Beni Suef (G3) at three seasons 2017, 2018 and 2019, in the experimental farm of El-Kasaseen Research Station, Agriculture Research Center. The results indicated that the mean performances of the three clones at three seasons for the herb and oil traits were significant variation present between all the recorded traits. Furthermore, mean squares due to environment (years) and interactions between genotypes $\mathrm{x}$ environments for all traits were significant, this result indicating that clones behaved differently under different years. The relatively high values of the linear regression coefficients on environmental means in clone G2 with high mean performance for fresh weight/plant, fresh weight of herb/plant and volatile oil yield/plant $(b=1.22$, $1.23,1.29$, respectively) reflected the suitability of this clone to favorable conditions. The most traits had nonsignificant deviation from regression $\mathrm{S}^{2} \mathrm{~d}$ values for $\mathrm{G} 1$ and $\mathrm{G} 2$ clones. G2 clone had the highest value of herb fresh weight/fedan and volatile oil yield/fedan (29.41 tones and $76.63 \mathrm{~L}$, respectively) and least non-significant deviation from regression $\left(\mathrm{S}^{2} \mathrm{di}\right)$. By gas liquid chromatograms for the essential oil, G1 clone recorded the highest percentage from Linalool, Geraniol, Eugenol and Iso menthone $(7.31 \%, 16.57 \%, 11.24 \%$ and $7.31 \%$, respectively), while G2 clone gave highly citronellol, $\alpha$-pinene and B-caryophyllene percentage (24.19, 1.31 and $7.28 \%$, respectively).
\end{abstract}

Keywords: Pelargonium graveolens, stability, variability, clones, gas liquid chromatography.

\section{INTRODUCTION}

Geranium (Pelargonium graveolens) is one of the most important export medical and aromatic plants in Egypt. It is used either as herb or volatile oil in industrial pharmaceuticals, therefore the economic value of geranium depends on the herb traits and percentage of oil. The improvement and development of these traits may be achieved through a successful breeding program. However, the essential oil of $P$. graveolens is extensively used in the perfumery and cosmetic industries. Geranium oil (citronellol, geraniol, and linalool) has smooth muscle relaxant properties, important skincare oil because it is good in opening skin pores and cleaning oily complexions, can be used in reducing pain due to post-herpetic neuralgia and treating dysentery, hemorrhoids, inflammation, heavy menstrual flows, even cancer (Farukh et al., 2014).

Ibrahim et al. (2013) evaluated three varieties of basil (French, Purple and Lemon basils) to some morphological variability and RAPD analysis for herb growth and oil yield characters. The analysis of variance showed highly significant differences between the varieties and cuts in the studied characters. Furthermore, the highest values of genotypic coefficients of variation (G.C.V \%) were obtained for some characters. this study showed the importance of herb dry yield and essential oil percent selection criteria for improving oil yield in sweet basil

The variation of essential oil constituents under varied agro climatic regions in India were studied by Bhaskaruni et al. (1990). The essential oil yield was higher at lower regions than at higher, the oil yield from plants grown in the moderate climate the high site was richer in menthone, citronellol, nerol and geraniol, while the oil produced from plants grown at lower locations were richer in isomenthone, linalool, citronellyl formate and an unidentified compound.

Geranium has been vegetatively propagated and both cultivars do not produce seeds. Therefore, it is expected that the cultivars have accumulated a large number of recessive mutations and a high degree of heterozygosis. Considerable intra-clonal variation has been reported in scented geranium (Peluugonium sp.) plants obtained from leaf (leaf + petiole) and root suckers (Skirvin and Janik, 1976; Janik et al., 1977).

Kulkarni et al. (1997) found significant intraclonal variation for essential oil content in vegetative propagated rose-scented geranium (Pelargonium sp.) cultivar, 'Bourbon'. However, no variation for morphological traits and some plants had isomenthone as the major constituent instead, some plants had citronellol and geraniol. The key constituents of geranium oil and plants with negligible amounts of loepi-y-eudesmol. A key constituent used in differentiating commercial geranium oils and a citronellol/geraniol ratio of approximately 1.4:1, citronellyl formate was significantly higher content than the parental cultivar. Finally, the clonal progeny of variant plants revealed the stability of variants through clonal generation of multiplication.

Hamouda (2003) indicated that all clones selected from cultivated Pelargonium graveolens, their 
plants obtained from different locations (Quetur, El Kanater, Beaniswafe and El-Dokki) in Egypt, were revealed variation in oil percentage and main oil constituents (geraniol, citronellol and linalool) between them.

The objectives of this study were to present results of the analysis of genotype $\times$ environment interactions, growth response, and stability of geranium (Pelargonium graveolens) clones grown in different environments. As well as investigate the genetic makeup of some clones from different locations in Egypt and select the most promising breeding method to be used as a program for improving geranium genetic traits under conditions of the region.

\section{MATERIALS AND METHODS}

Three geranium clones were collected from three different regions of Egypt, Al-Sharkia (G1), Ismailia (G2) and Beni Suef (G3) and used in the present study in three seasons 2017, 2018 and 2019, at the experimental farm of the El-Kasaseen Research Station. The cuttings of the three geranium clones were planted in a randomized complete block design with three replicates in the first October each year. Each replication comprised of 9 rows each row is about $6 \mathrm{~m}$ length with $70 \mathrm{~cm}$ between rows. The plants were cultured in the row with a distance of $30 \mathrm{~cm}$ between plants. To raise a good and healthy crop, all agricultural practices were carried out as recommended by the Egyptian Agriculture Ministry for geranium cultivation in sandy soils. The herb was cut at one time when $50 \%$ plants were flowered.

The data of 2017, 2018 and 2019 seasons were recorded on the following traits: plant height (P.H), fresh weight/plant (F.W/P), fresh weight of herb/plant (F.W.H/P), fresh weight of root/ plant (F.W.R/P), volatile oil percentage (\%) which was determined according to the British Pharmacopeia (1963) as a percent of fresh weight (V.O.P), volatile oil yield/plant (V.O.Y./P), herb fresh weight/fedan (H.F.W/F) and volatile oil yield/fedan which was calculated in proportion to the herb fresh weight (V.O.Y./F).

\section{Oil extraction:}

The determination of the essential oil percentage was done using a Clevenger type apparatus as mentioned by (Kapoor et al., 2004).

Oil gas chromatography: The volatile oil was analyzed using Dschrom 6200 Gas Chromatograph equipped with a flame ionization detector for separation of volatile oil constituents.

\section{Statistical analysis:}

Analysis of variance was computed for each of the growing seasons according to Snedecor and Cochran (1967), using L.S.D at $5 \%$ and $1 \%$ levels for comparison of different clones. Coefficient of variability values were estimated depends on phenotypic (P.C.V) and genotypic (G.C.V) variances using the following formula as suggested by Burton (1952).
P.C.V. $\%=\frac{\sqrt{v p}}{\bar{x}} \times 100$

G.C.V. $\%=\frac{\sqrt{v_{G}}}{\bar{x}} \times 100$

Where, $\sqrt{v p}=$ phenotypic standard deviation,

$\sqrt{v_{G}}=$ genotypic standard deviation,

and $\bar{x}=$ genotypes means.

$\mathrm{Vg}=\mathrm{MSG}-\mathrm{MSE}$

$\mathrm{Vp}=\mathrm{Vg}+\mathrm{Ve}$

$\mathrm{Vg}=$ Genotypic variance, $\mathrm{MSG}=$ Mean square due to germplasm, $\mathrm{MSE}=$ Error mean square,

$\mathrm{Vp}=$ Phenotypic variance, $\mathrm{Vg}=$ Genotypic variance, $\mathrm{Ve}=$ Error variance, i.e. MSE.

Stability analysis: Environments may consist of different locations, different years, different site preparation or management treatments. The importance of selecting stable genotypes by testing the available selections at different growth phases, fertility regimes or locations has been highlighted as $\mathrm{G} \times \mathrm{E}$ interaction can reduce genetic gains or make a geranium breeding program more complex and expensive. In the present investigation, stability parameters were estimated using Eberhart and Russel (1966) proposed model. According to them, a high yielding genotype with unit regression coefficient $(\mathrm{bi}=1)$ and the deviation from regression not significantly different from zero $\left(\mathrm{S}^{2} \mathrm{di}=0\right)$ is considered as the stable one. Clones which possessed high mean (general mean + two SE) only were considered for classification and characterization for adaptability (Cavalcanti and Gurgel, 1973).

\section{RESULTS AND DISCUSSION}

\section{Mean performances of the evaluated geranium clones:}

It is clear from Table (1) that there are different significant among the herb and oil traits between all the recorded traits. This was true with the three geranium clones at the cultivated three seasons. In the first season 2017, the geranium clone G3 gave the highest significant values for all the studied traits except volatile oil percentage the G1 clone was the best $(0.26 \%)$. In the second $2018 \mathrm{G} 1$ clone had the highest significant values for fresh weight/plant, fresh weight of herb /plant, fresh weight of root/plant, volatile oil yield/plant, herb fresh weight/fedan and volatile oil yield/fedan, On the other side, G2 and G3 clones produced the plant height and volatile oil percentage traits respectively ( $0.86 \mathrm{~m}$ and $0.22 \%$ ).

Further, results of the third season 2019 showed that G1 clone values were the highest for plant height, fresh weight of root/plant and volatile oil percentage traits $(1.92 \mathrm{~m}, 176.93 \mathrm{gm}$ and $0.32 \%$, respectively). Regarding the G2 and G3 clones, it noticed that the G2 clone gave the highest fresh weight/plant, fresh weight of herb/plant and volatile oil yield/plant $(3.14 \mathrm{~kg}, 2.98$ $\mathrm{kg}$ and $2.99 \mathrm{ml}$., respectively), while G3 clone had the highest value for fresh weight of herb/plant and volatile oil yield/Fedan traits. 
Table (1): Mean performance for the herb and volatile oil of three geranium clones' traits at three seasons (2017-2018-2019)

\begin{tabular}{|c|c|c|c|c|c|c|c|c|}
\hline Season & & & & 2017 & & & & \\
\hline Traits & $\begin{array}{l}\mathrm{PH} \\
(\mathrm{m})\end{array}$ & $\begin{array}{c}\text { F.W/P } \\
(\mathrm{kg})\end{array}$ & $\begin{array}{l}\text { F.W. H/P } \\
(\mathrm{kg})\end{array}$ & $\begin{array}{c}\text { F.W.R/P } \\
(\mathrm{gm})\end{array}$ & $\begin{array}{c}\text { V.O.P } \\
(\%)\end{array}$ & $\begin{array}{l}\text { V.O.Y./P } \\
(\mathrm{ml})\end{array}$ & $\begin{array}{c}\text { H.F.W/F } \\
\text { (ton) }\end{array}$ & $\begin{array}{c}\text { V.O.Y/F } \\
\text { (L) }\end{array}$ \\
\hline G1 & $0.52 \mathrm{~b}$ & $0.83 \mathrm{~b}$ & $0.77 \mathrm{~b}$ & $56.54 \mathrm{~b}$ & $0.26 \mathrm{a}$ & $1.63 \mathrm{~b}$ & $12.82 \mathrm{~b}$ & $32.69 \mathrm{~b}$ \\
\hline G2 & $0.52 \mathrm{~b}$ & $0.79 \mathrm{~b}$ & $0.73 \mathrm{~b}$ & $52.81 \mathrm{~b}$ & $0.25 \mathrm{a}$ & $1.86 \mathrm{~b}$ & $14.68 \mathrm{~b}$ & $37.19 \mathrm{~b}$ \\
\hline G3 & $1.16 \mathrm{a}$ & $1.58 \mathrm{a}$ & $1.43 \mathrm{a}$ & $149.18 \mathrm{a}$ & $0.21 \mathrm{a}$ & $2.99 \mathrm{a}$ & $28.58 \mathrm{a}$ & $59.76 \mathrm{a}$ \\
\hline LSD 0.05 & 0.13 & 0.23 & 0.24 & 63.79 & 0.06 & 0.76 & 2.60 & 15.20 \\
\hline LSD 0.01 & 0.20 & 0.36 & 0.38 & 99.32 & 0.10 & 1.18 & 4.04 & 23.66 \\
\hline Season & & & & 2018 & & & & \\
\hline Clones & $\begin{array}{l}\text { PH } \\
(\mathrm{m})\end{array}$ & $\begin{array}{c}\text { F.W/P } \\
(\mathbf{k g})\end{array}$ & $\begin{array}{l}\text { F.W. H/P } \\
\text { (kg) }\end{array}$ & $\begin{array}{l}\text { F.W.R/P } \\
\text { (gm) }\end{array}$ & $\begin{array}{c}\text { V.O.P } \\
(\%)\end{array}$ & $\begin{array}{l}\text { V.O.Y./P } \\
(\mathrm{ml})\end{array}$ & $\begin{array}{l}\text { H.F.W/F } \\
\text { (ton) }\end{array}$ & $\begin{array}{l}\text { V.O.Y/F } \\
\text { (L) }\end{array}$ \\
\hline G1 & $0.82 \mathrm{ab}$ & $0.88 \mathrm{a}$ & $0.82 \mathrm{a}$ & $56.67 \mathrm{a}$ & $0.20 \mathrm{ab}$ & $1.63 \mathrm{a}$ & $16.40 \mathrm{a}$ & $32.68 \mathrm{a}$ \\
\hline G2 & $0.86 \mathrm{a}$ & $0.75 \mathrm{ab}$ & $0.70 \mathrm{ab}$ & $50.00 \mathrm{ab}$ & $0.18 \mathrm{~b}$ & $1.23 \mathrm{ab}$ & $14.04 \mathrm{ab}$ & $24.60 \mathrm{ab}$ \\
\hline G3 & $0.72 \mathrm{c}$ & $0.46 \mathrm{c}$ & $0.42 \mathrm{c}$ & $32.77 \mathrm{c}$ & $0.22 \mathrm{a}$ & $0.90 \mathrm{~b}$ & $8.33 \mathrm{c}$ & $17.93 \mathrm{~b}$ \\
\hline LSD 0.05 & 0.05 & 0.15 & 0.13 & 7.64 & 0.03 & 0.42 & 2.66 & 8.41 \\
\hline LSD 0.01 & 0.07 & 0.23 & 0.21 & 11.90 & 0.05 & 0.65 & 4.15 & 13.09 \\
\hline Season & & & & 2019 & & & & \\
\hline Clones & $\begin{array}{l}\mathbf{P h} \\
(\mathbf{m})\end{array}$ & $\begin{array}{c}\text { F.W/P } \\
(\mathrm{kg})\end{array}$ & $\begin{array}{c}\text { F.W. H/P } \\
(\mathrm{kg})\end{array}$ & $\begin{array}{c}\text { F.W.R/P } \\
(\mathrm{gm})\end{array}$ & $\begin{array}{l}\text { V.O.P } \\
(\%) \\
\end{array}$ & $\begin{array}{c}\mathrm{V.O.Y} / \mathrm{p} \\
(\mathrm{ml})\end{array}$ & $\begin{array}{c}\text { H.F.W/F } \\
\text { (ton) }\end{array}$ & $\begin{array}{c}\text { V.O.Y/F } \\
\text { (L) }\end{array}$ \\
\hline G1 & $1.92 \mathrm{a}$ & $2.51 \mathrm{~b}$ & $2.34 \mathrm{~b}$ & $176.93 \mathrm{a}$ & $0.32 \mathrm{a}$ & $7.45 \mathrm{ab}$ & $46.86 \mathrm{~b}$ & $\begin{array}{c}148.97 \\
a b\end{array}$ \\
\hline G2 & $1.59 \mathrm{~b}$ & $3.14 \mathrm{a}$ & $2.98 \mathrm{a}$ & $164.17 \mathrm{a}$ & $\begin{array}{c}0.28 \\
a b\end{array}$ & $8.41 \mathrm{a}$ & $59.21 \mathrm{a}$ & $168.12 \mathrm{a}$ \\
\hline G3 & $1.60 \mathrm{~b}$ & $2.70 \mathrm{ab}$ & $2.49 \mathrm{ab}$ & $157.93 \mathrm{a}$ & $0.20 \mathrm{~b}$ & $5.02 \mathrm{~b}$ & $49.72 \mathrm{ab}$ & $100.47 \mathrm{~b}$ \\
\hline LSD 0.05 & 0.29 & 0.52 & 0.63 & 24.61 & 0.10 & 2.82 & 12.64 & 56.47 \\
\hline LSD 0.01 & 0.44 & 0.89 & 0.98 & 38.31 & 0.15 & 4.40 & 19.68 & 87.92 \\
\hline
\end{tabular}

${ }^{*} \mathrm{G} 1=$ Al-Sharkia, G2= Ismailia and G3= Beni Suef. plant height (P.H), fresh weight/plant (F.W/P), fresh weight of herb/plant (F.W.H/P), fresh weight of root/plant (F.W.R/P), volatile oil percentage (\%), volatile oil yield/plant (V.O.Y./P), herb fresh weight/fedan (H.F.W/F) and volatile oil yield/fedan (V.O.Y./F).

\section{Stability analysis:}

The significant mean squares due to environment (years) for all studied traits in Table (2) suggested that, environment (years) considerably influenced on the genotypic performance. The interactions between genotypes and environments for all traits were significant indicating that clones behaved differently under different years. This result was in accordance with Abdel-salam et al. (2010), with all traits. Significant mean square due to environments (linear) for plant height, fresh weight/plant, fresh weight of herb/plant and volatile oil percentage, indicating the differences between 3 years (environment) and their considerable influence on these traits.

The higher linear component of Genotypes $\times$ Environments than non-linear component for volatile oil yield/plant indicates the possibility of production of genotypes in different environments. However, the mean square due to environment + (Genotypes $\times$ Environments) was highly significant for plant height, fresh weight/plant, fresh weight of herb/plant, fresh weight of root/plant, volatile oil yield/plant, herb fresh weight/fedan, volatile oil yield/fedan. These results indicated that there was considerable interaction of genotypes with the environmental conditions in different years. On the other hand, the highly significant pooled deviation from linear regression determines degree of stability of each clone under the study.

The values of regression analysis showed in Table (3) indicated that clone (G1) had a high mean performance for plant height, fresh weight of root/plant, volatile oil percentage with significant regression close to unity ( $b=1.34,1.08,1.69$, respectively), indicating their suitability for all environments. The relatively high values of regression coefficients in genotype G2 with high mean performance for fresh weight/plant, fresh weight of herb/plant and volatile oil yield/plant $(b=$ $1.22,1.23,1.29)$ reflected the suitability of this clone to favorable conditions, like high fertility, timely sowing and good management practices. 
Table (2): Mean squares from stability analyses for herb and volatile oil traits of three geranium clones at three seasons, (2017-2018-2019)

\begin{tabular}{|c|c|c|c|c|c|c|c|c|c|}
\hline S.O.V & DF & $\mathbf{P H}$ & F.W/P & F.W.H/P & F.W.R/P & V.O.P & V.O.Y/P & H.F.W/F & V.O.Y/F \\
\hline Environments (years) & 2 & $2.63 * *$ & $11.16^{* *}$ & $9.85^{* *}$ & $33555^{* *}$ & $0.01 *$ & $84.61^{* *}$ & $4011.42 * *$ & $33845^{* *}$ \\
\hline Genotypes & 2 & $0.07 *$ & 0.08 & 0.07 & 1388 & 0.01 & 1.76 & 43.72 & 705 \\
\hline Genotypes $\times$ Environments & 4 & $0.23 * *$ & $0.49^{* *}$ & $0.43^{* *}$ & $4145^{* *}$ & 0.004 & $4.67 *$ & $181.50^{* *}$ & $1869^{*}$ \\
\hline Environment $+(\mathbf{G} \times \mathbf{E})$ & 6 & $1.03^{* *}$ & $4.04^{* *}$ & $3.57 * *$ & $13949^{* *}$ & $0.01 *$ & $31.32 * *$ & $1458.14^{* *}$ & $12528 * *$ \\
\hline Environmental (linear) & 1 & $1.00^{* *}$ & $1.00^{* *}$ & $1.00^{* *}$ & 1.00 & $1.00^{* *}$ & 1.00 & 1.00 & 1.00 \\
\hline Genotype $\times$ Environmental (linear) & 2 & $0.44 * *$ & $3.31 * *$ & $2.88^{* *}$ & $11238 * *$ & $-0.49 * *$ & $29.93 * *$ & $1371.22 * *$ & 12161 \\
\hline Pooled deviation & 3 & $0.06^{*}$ & 0.15 & 0.13 & 1807 & 0.0001 & 0.61 & 57.61 & 244.43 \\
\hline Pooled error & 18 & 0.02 & 0.07 & 0.06 & 765.59 & 0.002 & 1.23 & 29.68 & 492.11 \\
\hline
\end{tabular}

S.O.V = Source of variances, $\mathrm{DF}=$ Degree of freedom. $(\mathrm{G} \times \mathrm{E})=$ Genotypes $\times$ Environment. plant height $(\mathrm{P} . \mathrm{H})$, fresh weight/plant $(\mathrm{F} . \mathrm{W} / \mathrm{P})$, fresh weight of herb/plant $(\mathrm{F} . \mathrm{W} . \mathrm{H} / \mathrm{P})$, fresh weight of

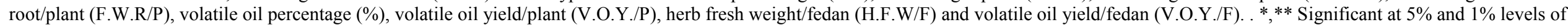
probability, respectively.

Table (3): Estimation of stability parameters for three genotypes in geranium for all studied traits at three seasons (2017-2018-2019)

\begin{tabular}{|c|c|c|c|c|c|c|c|c|c|c|c|c|c|c|c|c|c|c|c|c|c|c|c|c|}
\hline \multirow{2}{*}{ Gen } & \multicolumn{3}{|c|}{ PH } & \multicolumn{3}{|c|}{ FW/P } & \multicolumn{3}{|c|}{ FWH/P } & \multicolumn{3}{|c|}{ FWR/P } & \multicolumn{3}{|c|}{ V.O.P (\%) } & \multicolumn{3}{|c|}{ V.O.Y/P } & \multicolumn{3}{|c|}{ H.F.W/F } & \multicolumn{3}{|c|}{ V.O.Y/F } \\
\hline & $\begin{array}{l}X(m) \\
1.08\end{array}$ & $\mathbf{b}_{\mathbf{i}}$ & $S^{2} d$ & $\begin{array}{c}X(k) \\
1.51\end{array}$ & $\mathbf{b}_{\mathbf{i}}$ & $S^{2} d$ & $\begin{array}{c}X(\mathrm{~kg}) \\
1.41\end{array}$ & $\mathbf{b}_{\mathrm{i}}$ & $S^{2} d$ & $\begin{array}{c}\text { X (gm) } \\
99.7\end{array}$ & $\mathbf{b}_{\mathbf{i}}$ & $S^{2} d$ & $\begin{array}{l}X(\%) \\
0.24\end{array}$ & $\mathbf{b}_{\mathbf{i}}$ & $S^{2} d$ & $\begin{array}{c}\mathrm{X}(\mathrm{ml}) \\
3.46\end{array}$ & $\mathbf{b}_{\mathrm{i}}$ & $S^{2} d$ & $\begin{array}{l}X(\text { to }) \\
27.9\end{array}$ & $\mathbf{b}_{\mathbf{i}}$ & $S^{2} d$ & $\begin{array}{c}X(L) \\
69.2\end{array}$ & $\mathbf{b}_{\mathbf{i}}$ & $S^{2} d$ \\
\hline G1 & 1.09 & $1.34^{* *}$ & 0.017 & 1.41 & $0.84^{* *}$ & 0.042 & 1.31 & $0.84^{* *}$ & 0.029 & 96.71 & $1.08^{*}$ & 770.27 & 0.26 & $1.69^{* *}$ & -0.001 & 3.57 & $1.08^{* *}$ & 0.08 & 25.36 & $0.86^{* *}$ & 27.41 & 71.44 & $1.08^{* *}$ & 33.1 \\
\hline G2 & 0.99 & $0.98^{* *}$ & 0.03 & 1.56 & $1.22^{* *}$ & 0.064 & 1.47 & $1.23^{* *}$ & 0.048 & 88.99 & 1.02 & 531.33 & 0.24 & $1.55^{* *}$ & -0.001 & 3.83 & $1.29^{* *}$ & -0.26 & 29.41 & $1.23^{* *}$ & 11.18 & 76.63 & $1.29^{* *}$ & -103.7 \\
\hline G3 & 1.16 & $0.68^{*}$ & $0.11^{* *}$ & 1.58 & $0.95^{* *}$ & $0.28^{*}$ & 1.44 & $0.93^{* *}$ & 0.229 & 113.3 & 0.91 & $3353^{*}$ & 0.21 & -0.23 & -0.001 & 2.97 & $0.62^{* *}$ & 0.78 & 28.88 & $0.91^{* *}$ & $104.6^{*}$ & 59.39 & $0.62^{* *}$ & 311.7 \\
\hline
\end{tabular}

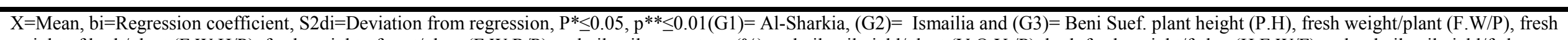
weight of herb/plant (F.W.H/P), fresh weight of root/plant (F.W.R/P), volatile oil percentage (\%), volatile oil yield/plant (V.O.Y./P), herb fresh weight/fedan (H.F.W/F) and volatile oil yield/fedan (V.O.Y./F). 
The most traits had non-significant $\mathrm{S}^{2}$ di values for $\mathrm{G} 1$ and $\mathrm{G} 2$ clones. G2 clone had the highest mean performance of herb fresh weight/fedan and volatile oil yield/fedan (29.41 tones and $76.63 \mathrm{~L}$, respectively) and least non-significant deviation from regression $\mathrm{S}^{2} \mathrm{di}$. However, the highest mean performance value for volatile oil percentage was recorded by G1 clone $(0.26 \%)$ with the least nun-significant deviation from regression $\mathrm{S}^{2}$ di. The clones $\mathrm{G} 1$ and $\mathrm{G} 2$ could be considered most stable for yield/fedan; also these clones had the highest volatile oil percentage, herb fresh weight/fedan and volatile oil yield/fedan. As reported by Perkins and Jinks (1968) and Finlay (1971) the stability like any other character is a heritable trait, thus these two genotypes (clones) can be judiciously used in geranium clones breeding programs as a source of genes for stability and high productivity.

\section{Genotypic (G.C.V) and phenotypic (P.C.V) coefficient of variation:}

The coefficient of phenotypic, genotypic and environmental variance for all the traits under study was presented in Table (4). The genotypic coefficient of variance was ranged from $6.60 \%$ (fresh weight/plant) to $25.03 \%$ (fresh weight of root/plant). Maximum genotypic coefficient of the variation was observed for the fresh weight of root/plant $(25.03 \%)$ followed by the volatile oil percentage (23.27\%). Phenotypic coefficient of variation ranged from $18.10 \%$ to $38.39 \%$ and the maximum phenotypic coefficient of the variation was observed for the volatile oil yield/plant and volatile oil yield/fedan $(38.39 \%)$ followed by the fresh weight of root/plant $(37.38 \%)$. In the present study, there was a close correspondence between genotypic and phenotypic coefficient of variation for plant height, fresh weight of root/plant and volatile oil percentage traits, it showed that, these characters were less influenced by the environment. However, the estimations of genotypic (G.C.V) and phenotypic (P.C.V) coefficients of variation exhibited differences between genotypic and phenotypic coefficient of variation for fresh weight/plant, fresh weight of herb/plant, volatile oil yield/p, herb fresh weight/fedan and volatile oil yield/fedan, it revealing that environmental effects were great importance for these traits.

Table (4): Genotypic (G.C.V) and phenotypic (P.C.V) coefficient of variability for all studied traits at three seasons, (2017-2018-2019)

\begin{tabular}{|c|c|c|c|c|c|c|}
\hline Traits & Vg & $V p$ & Ve & $\mathbf{X}$ & G.C.V\% & P.C.V\% \\
\hline P.H & 0.05 & 0.07 & 0.02 & 1.08 & 20.11 & 23.65 \\
\hline F.W/P & 0.01 & 0.08 & 0.07 & 1.51 & 6.60 & 18.79 \\
\hline F.W. H/P & 0.01 & 0.07 & 0.06 & 1.41 & 6.73 & 18.10 \\
\hline F. W. R/P & 622.21 & 1387.80 & 765.59 & 99.67 & 25.03 & 37.38 \\
\hline V.O.P & 0.003 & 0.005 & 0.002 & 0.24 & 23.27 & 30.04 \\
\hline V.O.Y./P & 0.53 & 1.76 & 1.23 & 3.46 & 21.09 & 38.39 \\
\hline H.F.W/F & 14.04 & 43.72 & 29.68 & 27.88 & 13.44 & 23.71 \\
\hline V.O.Y./F & 212.71 & 704.83 & 492.11 & 69.15 & 21.09 & 38.39 \\
\hline
\end{tabular}

$\mathrm{Vg}=$ Genotypic variance, $\mathrm{Vp}=$ Phenotypic variance, $\mathrm{Ve}=$ Error variance and $\mathrm{X}=$ general mean performance. plant height $(\mathrm{P} . \mathrm{H})$, fresh weight/plant (F.W/P), fresh weight of herb/plant (F.W.H/P), fresh weight of root/plant (F.W.R/P), volatile oil percentage (\%), volatile oil yield/plant (V.O.Y./P), herb fresh weight/fedan (H.F.W/F) and volatile oil yield/fedan (V.O.Y./F).

\section{Gas liquid chromatography (GLC) analysis of volatile oil:}

Oil constituents of herb cutting clones in Table (5) indicated that the clone G1 recorded the highest percentage from Linalool, Geraniol, Eugenol and Iso menthone $(7.31 \%, \quad 16.57 \%, \quad 11.24 \%$ and $7.31 \%$, respectively), while the clone G2 had highly citronellol, $\alpha$-pinene and B-caryophyllene percentage (24.19, 1.31 and $7.28 \%$, respectively). Furthermore, the clone G3 had the highest percentage of p-cymene component
$4.29 \%$, these results are also evident from Figures (1, 2 and 3), as described by Rasha et al. (2019), the essential oil of the geranium clones contained 10 major constituents which were $\alpha$-pinene, p-cymene, isomenthone, linalool, citronellyl formate, geranyl formate, citronellol, geraniol, egenoln $\beta$ rophyllene, the relative proportion of these constituents in the oil of geranium clones determine its quality and were found to be in harmony with the standard specifications of geranium essential oil. 
Table (5): Main components of volatile oil for the three Pelargonium graveolens L. clones using gas liquid chromatography (GC) method

\begin{tabular}{cccccccccccc}
\hline & \multicolumn{10}{c}{ Oil constituents (\%) } \\
\cline { 2 - 11 } Clones & Linalool & $\begin{array}{c}\text { Citronellol } \\
\text { formate }\end{array}$ & Citronellol & $\begin{array}{c}\text { Geraniol } \\
\text { formate }\end{array}$ & Geraniol & Eugenol & $\begin{array}{c}\boldsymbol{\alpha} \text { - } \\
\text { pinene }\end{array}$ & $\begin{array}{c}\text { p- } \\
\text { cymene }\end{array}$ & Isomenthone & $\begin{array}{c}\text { B- } \\
\text { caryophyllene }\end{array}$ \\
\hline $\mathbf{G 1}$ & 7.31 & 9.32 & 24.03 & 5.2 & 16.57 & 11.24 & 1.29 & 2.58 & 7.31 & 4.12 \\
$\mathbf{G 2}$ & 5.52 & 9.01 & 24.19 & 5.01 & 14.39 & 10.59 & 1.31 & 2.62 & 6.83 & 7.28 \\
$\mathbf{G 3}$ & 5.79 & 8.58 & 23.73 & 4.64 & 13.58 & 11.02 & 1.30 & 4.29 & 5.66 & 5.19 \\
\hline
\end{tabular}

$(\mathrm{G} 1)=$ Al-Sharkia, $(\mathrm{G} 2)=$ Ismailia and $(\mathrm{G} 3)=$ Beni Suef

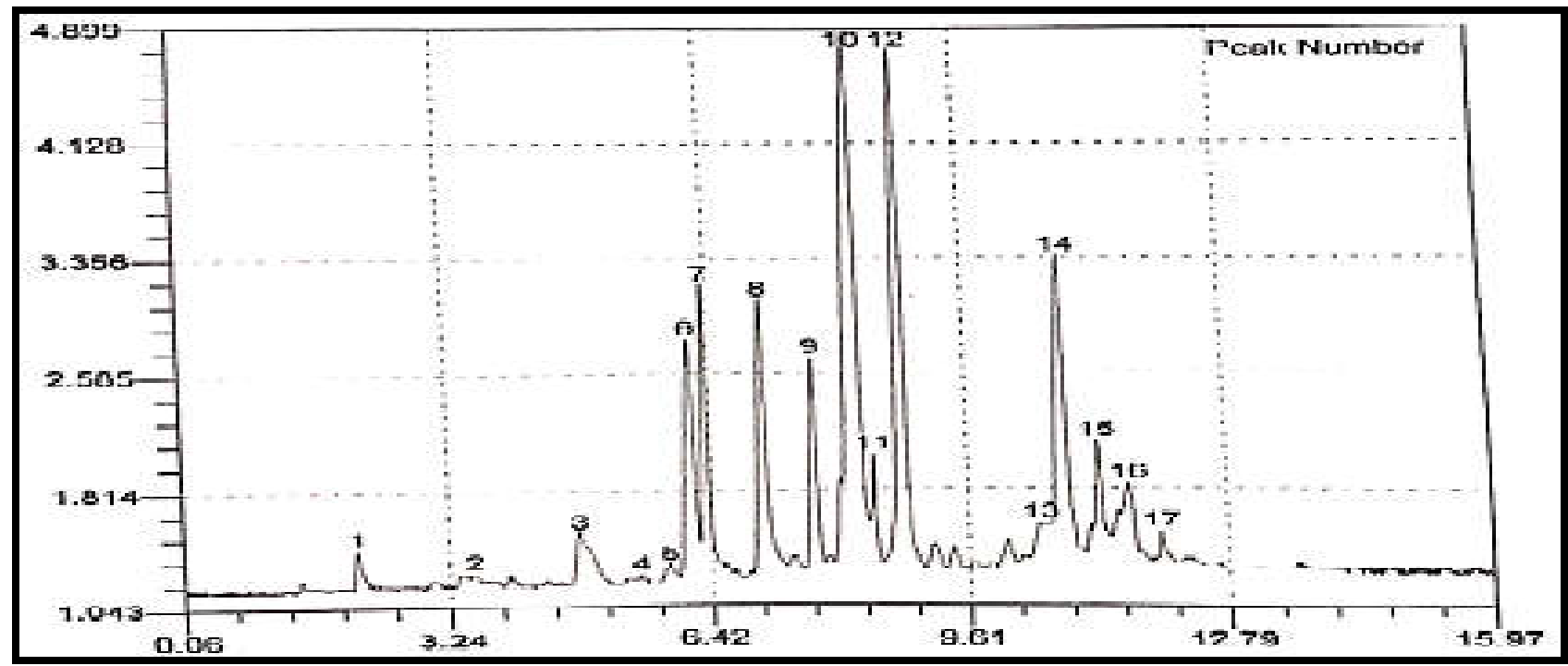

Figure (1): Gas liquid chromatography (GLC) analysis of volatile oil G1 clone.

1= $\alpha$-pinene, $3=$ P-cymene, $6=$ Isomonthone, $7=$ Linalool, 8= Citronelyl format, 9= Geronyl format, 10= Citronelol, 12= Geroniol, 14= Eugenol, 16= B-Caryophyllene

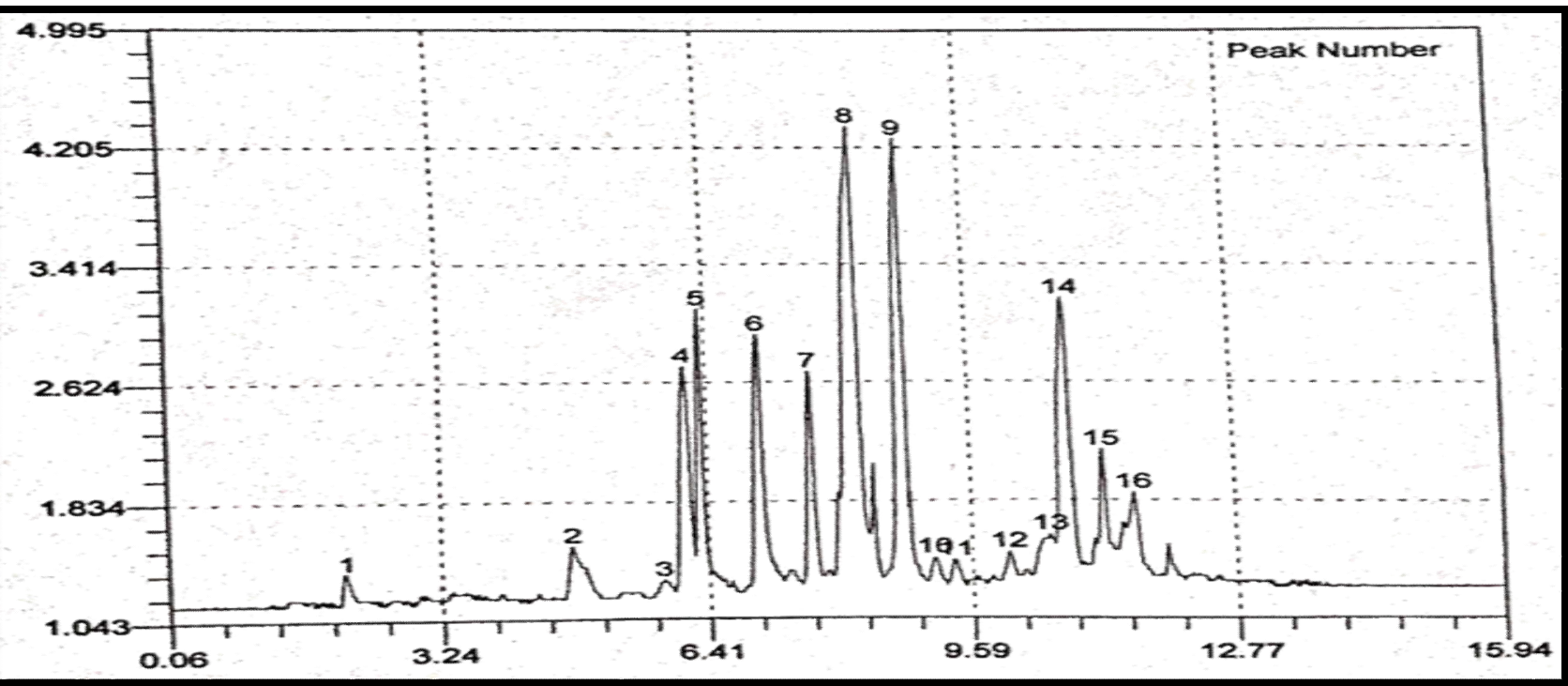

Figure (2): Gas liquid chromatography (GLC) analysis of volatile oil G2 clone.

1= $\alpha$-pinene, $2=$ P-cymene, 4= Isomonthone, 5= Linalool, 6= Citronelyl format, 7= Geronyl format, 8= Citronelol, 9= Geroniol, 14= Eugenol, 16= B-Caryophyllene 


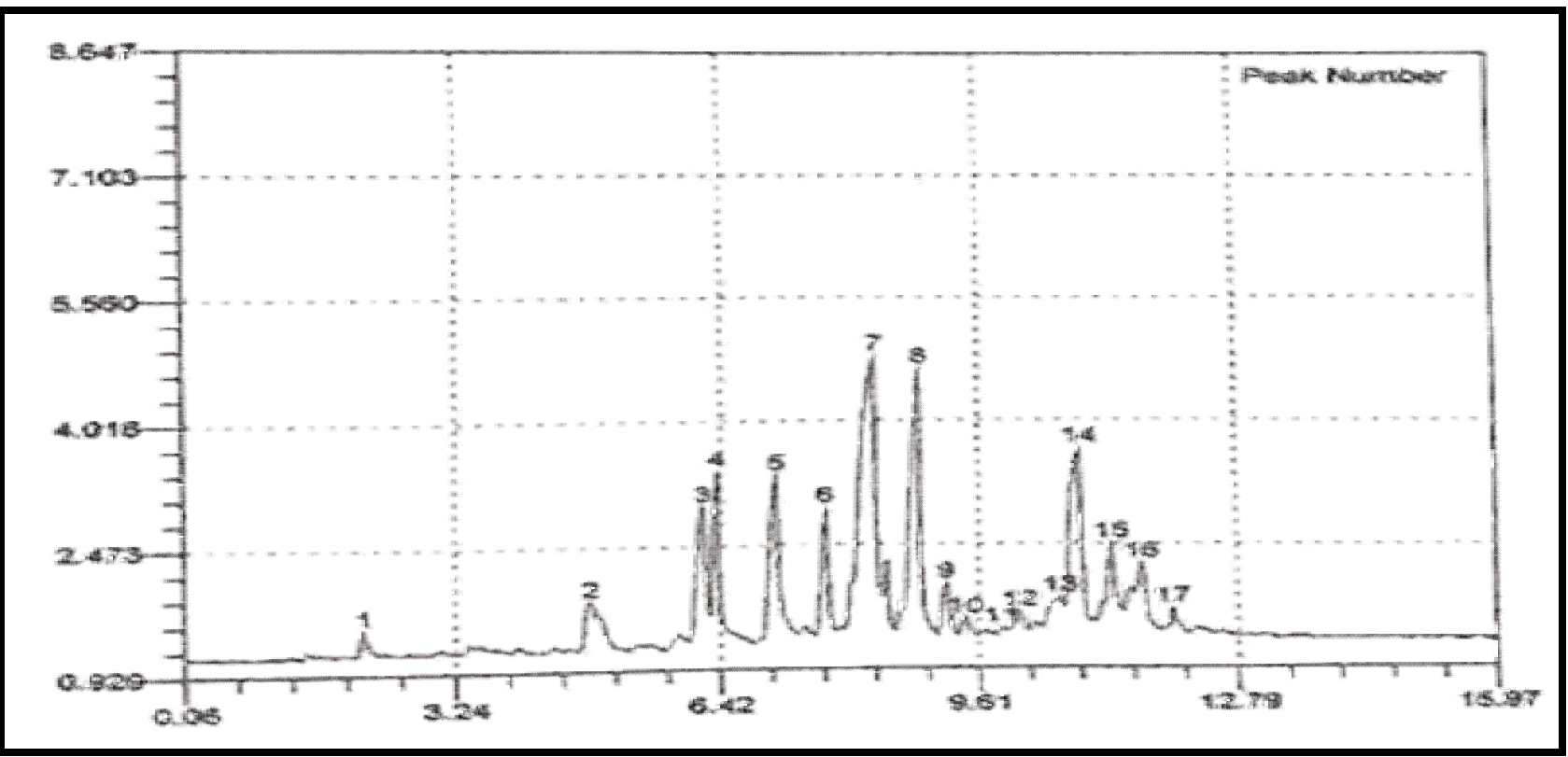

Figure (3): Gas liquid chromatography (GLC) analysis of volatile oil G3 clone.

$1=\alpha$-pinene, $2=$ P-cymene, $3=$ Isomonthone, $4=$ Linalool, $5=$ Citronelyl format, $6=$ Geronyl format, $7=$ Citronelol, $8=$ Geroniol, 14= Eugenol, 16= B-Caryophyllene

\section{CONCLUSION}

Based on the study results, some geranium clones under the study had stable for herb and volatile oil phenotype characters. Significant mean square due to environments (linear) for plant height, fresh weight/plant, fresh weight of herb/plant and volatile oil percentage, indicating the differences between 3 years (environment) and their considerable influence on these traits. However, the mean square due to environment + (Genotypes $\times$ Environments) was highly significant for plant height, fresh weight/plant, fresh weight of herb/plant, fresh weight of root/plant, volatile oil yield/plant, herb fresh weight/fedan, volatile oil yield/fedan. These results indicated that there was considerable interaction of genotypes with the environmental conditions in different years. From values of regression analysis a clone (G1) had a high mean performance for plant height, fresh weight of root/plant, volatile oil percentage with significant regression close to unity $(b=1.34,1.08,1.69$, respectively), that indicating their suitability for all environments. The relatively high values of regression coefficients in clone G2 with high mean performance for fresh weight/plant, fresh weight of herb/plant and volatile oil yield/plant $(b=1.22,1.23,1.29)$ reflected the suitability of this clone to favorable conditions, like high fertility, timely sowing and good management practices. It could be concluded that, the clones $\mathrm{G} 1$ and G2 could be considered most stable for yield/fedan; also these clones had the highest volatile oil percentage, herb fresh weight/fedan and volatile oil yield/fedan. these two genotypes (clones) can be judiciously used in geranium clones breeding programs as a source of genes for stability and high productivity.

\section{REFERENCES}

AbdEl-Salam, M. M. M, I. S. El-Demardash and A. H. Hussein (2010). Phenotypic Stability Analysis, Heritability and Protein Patterns of snake Cucumber Genotypes. Journal of American Science, 6(12): 503-507.

Bhaskaruni, R. R., P. S. Kakaraparthi, V. S. P. Eranki and I. R. Srinivas (1990).Variation in Yields and Quality of Geranium (Pelargonium graveolens L' Hér. ex Aiton) under Varied Climatic and Fertility Conditions. Journal of Essential Oil Research, 2: 73-79.

Burton, G. W. (1952). Quantitative inheritance in grasses. Proceeding $6^{\text {th }}$ International Grassland Congress, 1: 227-283.

British pharmacopoeia (1963). Determination of Volatile Oil in Drugs. The pharmaceutical press, 17, Bloomsbury square, London, WCI. England, Xiii, 112.

Cavalcanti, G. R. A. and J. T. A. Gurgel (1973). Eucalyptus seed production in Brazil. In "Seed Processing", Proc. IUFRO Wkg. Group on Seed Problems, Bergen, Vol. II, Paper 8.

Eberhart, S. A. and W. A. Russell (1966). Stability parameters for comparing varieties. Crop Science, $6: 36-40$.

Farukh, S. S., H. Zhang and W. N. Setzer (2014). Composition of geranium (Pelargonium graveolens) essential oil from Tajikistan. American Journal of Essential Oils and Natural Products, 2(2): 13-16.

Finlay, K. W. (1971). Breeding for yield in barley. Proceedings of international barley genetic symposium, 2: $345-388$. 
Hamouda, A. M. A. (2003). Propagation of some medicinal and aromatic plants through tissue culture technique. Ph.D Thesis, Agric. (Horticulture - Floriculture), Fac. Agric., Zagazig University.

Ibrahim, M. M., K. A. Aboud and A. M. F. Al-Ansary (2013). Genetic variability among three sweet basil (Ocimum basilicum 1.) varieties as revealed by morphological traits and RAPD markers. World Applied Sciences Journal, 24(11): 1411-1419.

Janik, J., R. M. Skirvin and R. B. Janders (1977). Comparison of in vitro and in vivo tissue culture systems in scented geranium. J. Hered., (68): 62-64.

Kapoor, R., B. Giri and K. G. Mukerji (2004). Improved growth and essential oil yield and quality in Foeniculum vulgare mill on mycorrhizal inoculation supplemented with P-fertilizer. Bioresource Technology, 93(3): 307-11.
Kulkarni, R. N., K. Baskaran, S. Ramesh and S. Kumar (1997). Intra-clonal variation for essential oil content and composition in plants derived from leaf cuttings of rose-scented geranium (Pelargonium sp.). Industrial Crops and Products, 6(2): 107-112.

Perkins, J. M. and J. L. Jinks (1968). Environmental and genotype environmental components of variability. Multiple lines and crosses. Heredity, London, 23: 339 - 356.

Rasha, I. M. H., M. A. Rashed and M. M. A. Sidky (2019). Development of invitro somaclonal variation for Pelargonium graveolens l'herit, ait. $14^{\text {th }}$ Conf. Agric. Develop. Res., Fac. of Agric., Ain Shams Univ., March, 2019, Cairo, Egypt Special Issue, 27(1): 563 - 577.

Skirvin, J. M. and J. Janik (1976). Tissue culture induced variation in scented Pelargonium spp. J. Am. Sot. Hort. Sci., 101: 281-290.

Snedecor, G. W. and W. G. Cochran (1967). Statistical methods. Oxford and IBH. Publishing Co. $6^{\text {th }}$ ed., pp 503.

\section{الثبات الوراثي والتباين لصفات العشب والزيت الطيار في نبات العتر \\ محمد عادل فضل عبد الدايم الطحاوي، أماني حافظ عبد الله محمود غريب، عمرو أحمد السيد \\ قسم بحوث تربية الخضر و النباتات الطبية والعطرية، معهد بحوث البساتين، مركز البحوث الزئية الزراعية}

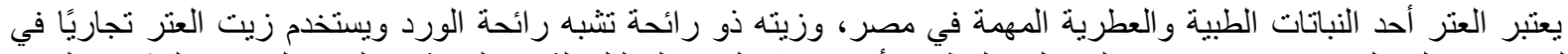

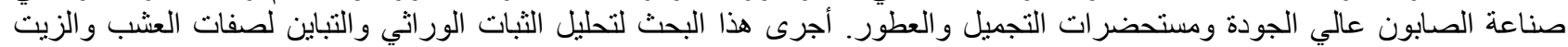

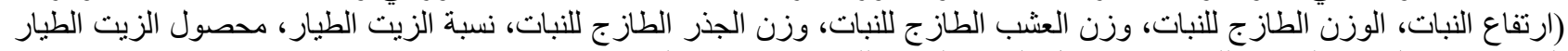

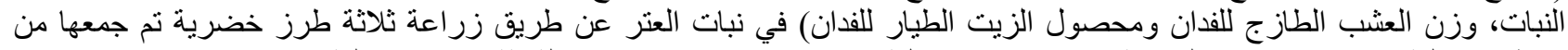

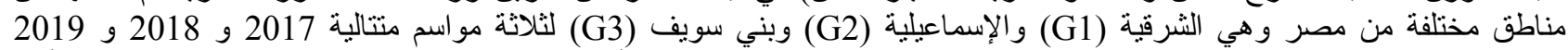

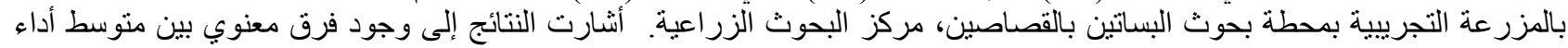

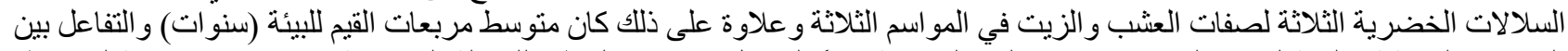

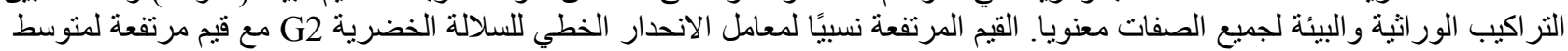

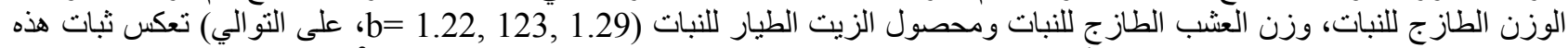

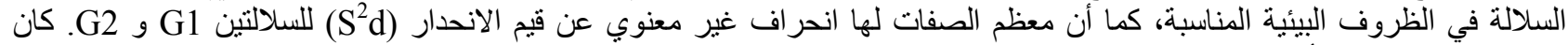

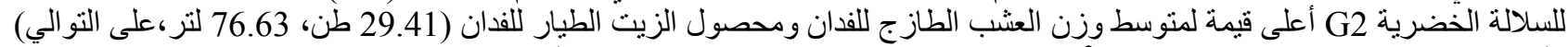

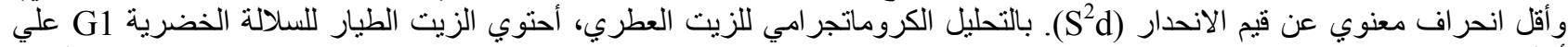

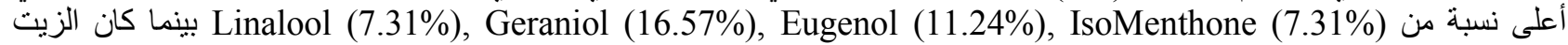
الطيار للسلالة G2 به نسبة عالية من (1.31\%), B-caryophyllene (7.28\%. 